\title{
The Application of Problem Based Learning (PBL) Approach for Elementary Schools Teachers
}

\author{
Rizky Amelia \\ Elementary School Teacher Education \\ University of Lambung Mangkurat \\ Banjarmasin, Indonesia \\ rizkyamelia@ulm.ac.id
}

\begin{abstract}
The purpose of this study was to describe the teacher's skills in applying the Problem Based Learning (PBL) approach to Indonesian language subjects for elementary schools in Sijunjung through training activities. The method used was a descriptive qualitative approach — techniques for collecting data through documentation and observation. The research subjects were elementary school teachers in Sijunjung District, which amounted to 101 teachers from 13 schools. The results obtained that through training activities teachers can design, practice, or simulate learning Indonesian using PBL. teachers as educators and as instructors could improve the quality of learning and can improve their profession as professional teachers.
\end{abstract}

Keywords-PBL, elementary school

\section{INTRODUCTION}

Problem Based Learning (PBL) is a learning model by exposing students to practical problems as a foundation in learning. This shows that the PBL model directs the active role of self in solving problems it faces with its knowledge [1]. Therefore this model can improve students' critical thinking skills [2], encourage initiative in work, and can develop interpersonal relationships in their groups.

In KTSP, the focus of learning is directed at developing all student competencies. Students are helped so that their competencies appear optimally. Through KTSP, students will be taken to the field of knowledge and application of knowledge acquired through learning. Thus, student competence in aspects of ability, ability, and knowledge (abilities, skills, and knowledge) will develop through the teaching and learning process.

According to Wright, there are three important elements in the teaching and learning process. The three elements are (1) the purpose of learning, (2) experience or teaching and learning process, and (3) learning outcomes. These three elements have reciprocal and reciprocal influences [3]. That is, the determination of learning objectives will affect the teaching and learning process, the teaching and learning process will affect student learning outcomes, and student learning outcomes are also influenced by the goals set.

Problems related to the first element are learning problems because they have been formulated according to the curriculum used. On the other hand, the problem of learning outcomes is a complex problem because it is influenced by several factors, such as the experience of students when learning takes place. Therefore, one problem that needs to be considered to review the success of the teaching and learning process is the involvement of students in learning. Students must be actively involved in learning.

The intensity of student involvement in learning is influenced by various factors. One of the main factors is the ability of students to understand the subject matter presented. Without understanding the subject matter, students will have difficulty involving themselves in the teaching and learning process. Therefore, the ability to understand the subject matter is a fundamental factor that needs to be considered. One way to help students understand the subject matter is that the teacher must be able to create a pleasant learning atmosphere for students.

Fun learning is meaningful learning for students. Students are directly involved in building their own understanding and in finding the concepts or knowledge they learn. Through direct involvement, the students will have experience in learning, and the lessons are meaningful. one of them is through PBL.

other than that Based on observations, the teachers are still monotonous in learning Indonesian. When children are told to make assignments as instructed by the teacher, writing is collected, examined, and returned. This activity continues to be carried out so that students get bored in learning.

Therefore training activities are used to use the PBL model in learning Indonesian. The activity that will be carried out is to train elementary school teachers in Sijunjung in implementing the PBL approach in Basic Indonesian subjects. The purpose of this study was to explain the teacher's skills in applying the PBL approach to Indonesian language subjects for elementary schools in Sijunjung.

\section{METHOD}

The method used is a descriptive qualitative approach. techniques for collecting data through documentation and observation. The research subjects at Sijunjung District, which amounted to 101 teachers from 13 schools. The teacher was given training on the application of PBL in primary schools, especially Indonesian subjects. activities are carried out through lecture, assignments and simulation methods. 


\section{RESULTS AND DISCUSSION}

PBL implementation in learning for elementary school teachers in Sijunjung is carried out through several stages of making Indonesian language learning plans with PBL approaches, and simulating the application of PBL approaches in Indonesian language learning, assignments, and simulation. the lecture method is used to convey material that is theoretical. assignment method $t$ to strengthen skills mastery in developing Indonesian language learning through PBL learning. simulation method to try to apply the PBL model in learning Indonesian in elementary school.

The results of community service activities indicate that the application of PBL learning provided by the trainer is very helpful for teachers in understanding the learning approach. This understanding can occur because in training the teacher is faced directly with the material that is closely related to learning in school so that the participants' schemata in accordance with the topic of discussion are easily raised. This is consistent with the opinion of Burn, Roe, and Ross which states that for understanding, students need to have schemata according to teaching material [4].

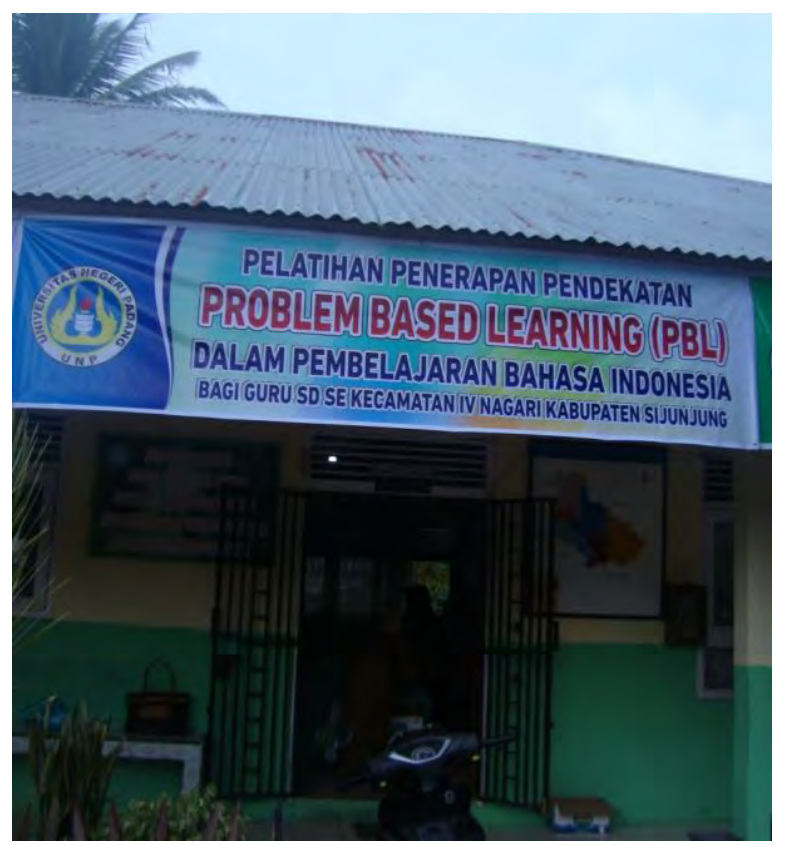

Fig. 1. Outside of the training site

The activity was carried out thanks to the good cooperation between the implementing team and the training participants, especially the Head of the UPTD, the SD Supervisor, and the Principal of the Elementary School in Sijunjung. In accordance with the opinion of Dahar which states that learning objectives can direct the flow of student learning and increase motivation to learn.

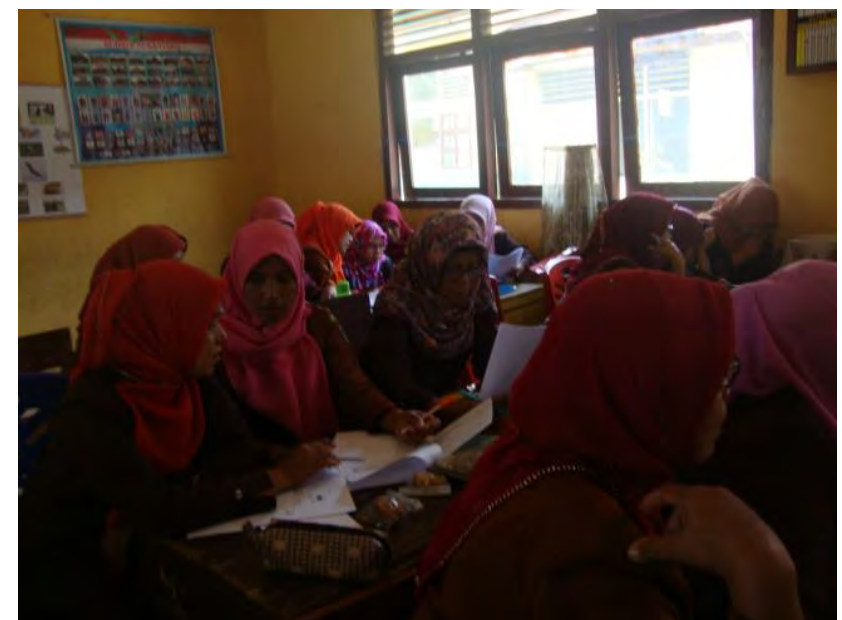

Fig. 2. Teachers doing assignment

However, in carrying out the learning training with the PBL approach, there are still teachers who are hesitant when doing assignments. This doubt arises because in providing examples of learning with the PBL approach training is only given to reading aspects, while Indonesian language learning activities include aspects of listening, speaking, reading and writing. The training participants looked enthusiastic and motivated in participating in training activities. This motivation arises because they are confident in the application of PBL according to the theory and examples are given. This is in accordance with the opinion of Slavin which states that in order to increase student motivation, teacher learning must try to attract students' interests with ingredients that match their needs, and how to present it which can increase their curiosity about the material itself.

The PBL process is carried out if the teacher is prepared with all the necessary tools (problems, supplementary forms, etc. Students must have formed small groups. According to M. Taufiq Amir, In this PBL process 7 processes are generally carried out, namely: (1) Clarifying unclear terms and concepts, (2) Formulating problems, (3) Analyzing problems, (4) Managing your ideas and systematically analyzing them in, (5) Formulating learning goals, (6) Finding additional information from other sources (outside group discussions), (7) Synthesize (combine) and test new information, and make reports for classes.

These seven steps can take place in several group meetings. Depending on the conditions and context in each class, there are those who run it with 3 or 4 meetings. According to Nurhadi PBL stages are 5. "The five stages begin with the teacher introducing students to a problem situation and ending with the presentation and analysis of student work" [5].

- Stage 1: Student orientation to problems; The teacher explains the learning objectives, explains the logistics needed, motivates students to be involved in solving the problems they choose.

- Stage 2: Organizing students to study; The teacher helps students define and organize learning tasks related to the problem. 
- Stage 3: Guiding individual investigations and groups; The teacher encourages students to gather appropriate information, carry out experiments, to get explanations and solve problems.

- Stage 4: Develop and present works; The teacher helps students plan and prepare appropriate works such as reports, videos and models and helps them share assignments with their friends.
- Phase 5: Analyze and evaluate the problem-solving process; The teacher helps students reflect or evaluate their investigations and the processes they use.

In general, the lecture stage with the problem-based learning model can be seen in the following Table I.

TABLE I. THE LECTURE STAGE WITH THE PROBLEM-BASED LEARNING MODEL

\begin{tabular}{|l|l|l|}
\hline Phase to & \multicolumn{1}{|c|}{ Lecturer Activity } & \multicolumn{1}{c|}{ Trainer Activity } \\
\hline 1 & $\begin{array}{l}\text { Orient students to the problems } \\
\text { presented or made by students, } \\
\text { and relate to the goals of the } \\
\text { lecture }\end{array}$ & $\begin{array}{l}\text { After the lecturer explains the purpose of the lecture with the } \\
\text { material being presented, explains the logistics needed, motivates, } \\
\text { then the students immediately actively observe and examine the } \\
\text { problem they chose }\end{array}$ \\
\hline 2 & $\begin{array}{l}\text { Organize students for lecture } \\
\text { activities in accordance with the } \\
\text { classroom settings }\end{array}$ & $\begin{array}{l}\text { Students try to finalize \& organize lecture tasks related to the } \\
\text { problem. }\end{array}$ \\
\hline 3 & $\begin{array}{l}\text { Guiding students in individual } \\
\text { and group investigations }\end{array}$ & $\begin{array}{l}\text { Students try to collect appropriate information, carry out } \\
\text { experiments to get explanation and problem-solving. }\end{array}$ \\
\hline 5 & $\begin{array}{l}\text { Develop and present student } \\
\text { presented or made }\end{array}$ & $\begin{array}{l}\text { Students plan appearances and prepare appropriate works such as } \\
\text { reports, videos, models and help them to share assignments with } \\
\text { their friends. }\end{array}$ \\
\hline $\begin{array}{l}\text { Analyze and evaluate the } \\
\text { problem-solving process that } \\
\text { has been done }\end{array}$ & $\begin{array}{l}\text { Lecturers help students to reflect or evaluate their investigations } \\
\text { and the process they use. }\end{array}$ \\
\hline
\end{tabular}

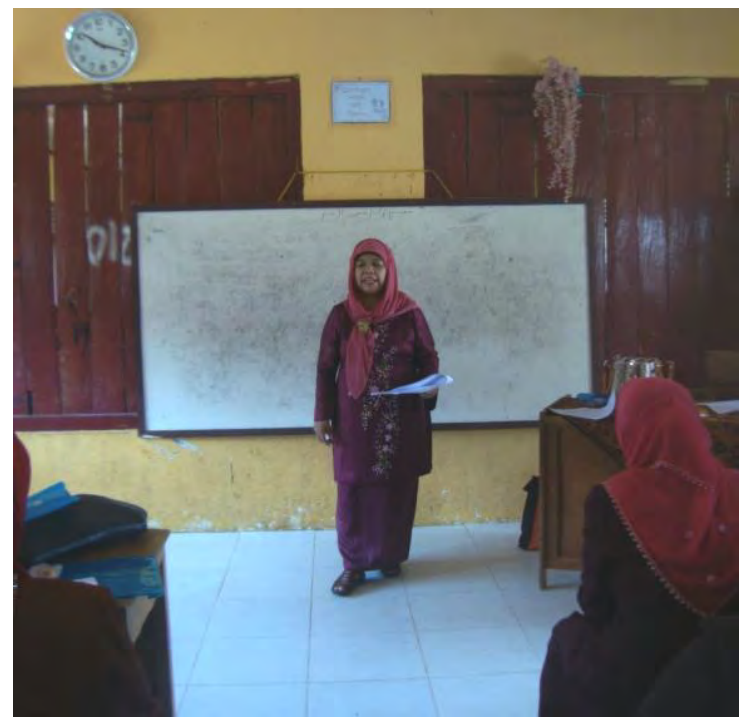

Fig. 3. Explain by Lecturer about PBL

In problem-based learning, you need to be aware that problem-solving is dominated by lecturers, even though at that time students are not motivated or there is no idea to get the way to problem-solving. If this happens what the lecturer has to do is give bait, lure, ladder as a bridge (according to the student's situation) so that students can find the expected solution. In other words, in this lecture model, the lecturer should provide scaffolding, which is to provide a large amount of assistance to students during the initial stages of the lecture and then the student takes on increasingly greater responsibility as soon as he can do it. The assistance is in the form of instructions, warnings, encouragement, describing the problem into the problem-solving steps, giving examples or anything else, which allows students to grow independently.

Problem Based Learning is based on cognitive psychology and constructivist views about learning. This learning model is 
in accordance with the desired principles of Contextual Teaching and Learning (CTL), namely: inquiry, construction and emphasizing higher level thinking. This model is suitable to be given in elementary school Indonesian learning. The following is an explanation of Indonesian learning activities which cover aspects of listening, speaking, reading and writing.

\section{A. Reading Learning in Elementary School}

Reading is basically a complex activity that involves many things, not only voicing writing but also involves the following processes: visual, idea, psycholinguistic, metacognitive and technological. As a visual process, read verbal words. reading is a meaningful interpretation of written or printed verbal symbols [6]. reading is part of the act of responding to the text with the meaning that corresponds to the written, verbal symbol.

In learning to read, the teacher must use the reading process; this process is related to activities to understand the contents of the reading, namely the reading process which includes the stages of pre-reading, reading, and post-reading. In using this activity, the teacher can do the following reference [4]. Pre-read activities, intended to arouse student behavior and motivate students so that they are interested in reading they will read or to generate student schemes (Piaget). 2). Reading activities, carried out after students have a general picture (schemata) about the reading that will be read. 3). Post-reading activities, see students' understanding of reading that has been read in terms of content, understanding

\section{B. Writing Learning in Elementary School}

Writing is one of the skills needed in learning Indonesian. By writing students can recognize their abilities and potential, know where their knowledge about something, develop ideas and reasons, absorb, and master information about something or can broaden their horizons, review and assess these ideas. active and can also help solve problems [7].

Writing is a process. As a process, writing is a series of activities that occur and involve several phases (stages), namely pre-writing (preparation), writing/compiling (developing essay content), revisions (repairs/completion of writing), editing (improving sign $\mathrm{read} / \mathrm{spelling}$ ) and publication (increased writing) [8]. This activity is very helpful for beginner writers like elementary school students.

\section{Listening Learning in elementary school}

Listening can be defined as the activity of receiving messages using spoken language as a medium. In oral communication that is least visible, (1) the speaker is the messenger, (2) the message or content of the conversation and, (3) the channel or media (direct speaker, telephone, radio or TV audience). The teacher plays an important role in the process of learning to listen. PAIKEM will be able to make listening learning real and meaningful. Students learn to listen by listening and learning to read, learning to write by writing.

\section{Learning to speak in elementary school}

Many limitations in speaking. According to Miles speaking is to say articulation sounds for words to express, express and convey one's thoughts, ideas and feelings in the form of language sounds [9]. While the ability to speak is the ability to speak words to convey ideas, thoughts and feelings and express feelings (happy, hate, happy) to others.

The ability to speak is a demand that must be mastered, especially for a teacher. How can students receive information from a teacher if the ability to explain or answer questions asked by students if the teacher demands students to speak well? These conditions indicate that in addition to having to master the theory of speaking, also must be skilled in speaking and able to implement it in the teaching and learning process. In other words, as a teacher, the teacher is required to be skilled at asking questions, multiplying information, arguing and skillfully attracting students' attention and sympathy.

\section{E. Speaking process}

Speaking is an activity carried out to hold social interactions. In class, speaking activities are more often associated with the lack of ability of teachers to manage classes rather than discussing how important students have the ability to speak. According to Cox in the teaching and learning process, students develop the ability to speak vertically not horizontally [10]. They have been able to express the message in full or incomplete. In line with the development of the language, the ability to speak is perfect, the choice of words is precise, the structure is correct, and the sentences are varied.

\section{CONCLUSION}

The application of PBL on Indonesian subjects for primary school teachers, through training activities, went well and smoothly. The results of community service activities indicate that the application of PBL learning provided by the trainer is very helpful for teachers in understanding the learning approach. Most teachers are able to understand and meet the criteria as instructors for the application of the PBL approach to learning Indonesian. This can be seen in the work carried out, namely the design of learning with the PBL approach prepared during the training.

\section{REFERENCES}

[1] S. A. Suriazdin, Z. Zainuddin, and A. I. Mahardika, "Pengembangan perangkat pembelajaran fisika berorientasi pada model problem based learning di SMPN 24 Banjarmasin," Berkala Ilmiah Pendidikan Fisika, vol. 3, no. 1,pp. 60-65, 2015.

[2] F. Royantoro, M. Mujasam, I. Yusuf, and S. W. Widyaningsih, "Pengaruh Model Problem Based Learning terhadap Higher Order Thinking Skills Peserta Didik," Berkala Ilmiah Pendidikan Fisika, vol. 6, no. 3, 2018.

[3] A. Wright, Pictures for Language Learning, Glasgow: Cambridge University Press, 1992.

[4] R. Burns, and Ros, Teaching Reading In Today in Elementary School. Boston: AllBacon, 1996.

[5] Ministry of National Education.2002. Contextual Approach. Jakarta: Ministry of National Education; Directorate General of Primary and Secondary Education.

[6] S. Rahma, Behavior and habits of children like to read cases of urban families in Surabaya, Jakarta: LP3ES, 1997. 
[7] A. Sabarti, Indonesian Language, Jakarta: Ministry of Education and Culture, 1991

[8] G. E. Tompkins, Teaching Writing: Balancing Process and Product. New York: Macmillan College Publishing Company, 1994.

[9] M. B. Miles, and A. M. Huberman, Qualitative data analysis, Translation by Jetjep Rohendi Rohidi, Jakarta: University of Indonesia Publisher, 1992.
[10] C. Cox, and Z. James, Teaching reading with children's literature. New York: Macmillan Publishing Company, 1993. 